\title{
molecules
}

ISSN 1420-3049

www.mdpi.com/journal/molecules

Article

\section{Chemical Constituents from Stem Bark and Roots of Clausena anisata}

Jules Lobe Songue ${ }^{1,2, *}$, Kouam ${ }^{1}$, Etienne Dongo ${ }^{3}$, Theophile Ngando Mpondo ${ }^{1}$ and

Robert L. White ${ }^{2, *}$

1 Department of Chemistry, University of Douala, Cameroon, P.O. Box 24157, Douala, Cameroon; E-Mails: lobejules@yahoo.fr (J.L.S.); jkouam2000@yahoo.fr (K.);

t_ngando_mpondo@yahoo.fr (T.N.M.)

2 Department of Chemistry, Dalhousie University, 6274 Coburg Road, P.O. Box 15000, Halifax, NS B3H 4R2, Canada; E-Mail: robert.white@dal.ca

3 Department of Organic Chemistry, University of Yaounde I, Cameroon, P.O. Box 812, Yaounde, Cameroon; E-Mail: dongoet@yahoo.fr

* Authors to whom correspondence should be addressed; E-Mails: lobejules@yahoo.fr (J.L.S.); robert.white@dal.ca (R.L.W.); Tel.: +237-9616-2081/7995-4354 (J.L.S.);

Tel./Fax: +1-902-494-6403 (R.L.W.).

Received: 11 October 2012; in revised form: 14 November 2012 / Accepted: 15 November 2012 / Published: 20 November 2012

\begin{abstract}
Phytochemical investigations on the stem bark and roots of the tropical shrub Clausena anisata led to the isolation and characterization three carbazole alkaloids: girinimbine, murrayamine-A and ekeberginine; two peptide derivatives: aurantiamide acetate and $N$-benzoyl-L-phenylalaninyl- $N$-benzoyl-L-phenylalaninate; and a mixture of two phytosterols: sitosterol and stigmasterol. The structures of these compounds were established by nuclear magnetic resonance $\left({ }^{1} \mathrm{H}-\mathrm{NMR},{ }^{13} \mathrm{C}-\mathrm{NMR}, \mathrm{COSY}, \mathrm{HSQC}, \mathrm{HMQC}\right.$, HMBC and NOESY) spectroscopy and electrospray ionization mass spectrometry (MS).
\end{abstract}

Keywords: Rutaceae; Clausena anisata; stem bark and roots; carbazole alkaloids; peptide derivative; phytosterol 


\section{Introduction}

Clausena anisata (Will). Hook.f. ex .benth., is a tropical shrub or tree growing up to ten meters in height in and on the margins of evergreen forests [1]. Different parts (stem bark, roots, and leaves) of this plant are widely used in traditional medicine to treat many diseases. Traditional healers in Tanzania use Clausena anisata against oral candidiasis and fungal infections of the skin [2], whereas in the Temeke district (Daressalam, Tanzania), Clausena anisata is used against epilepsy and as an anticonvulsant [3]. In some parts of Africa and in the Philippines, the burning of fresh leaves is utilized to repel mosquitoes [4]. Previous phytochemical investigations on this taxon yielded mostly carbazole alkaloids [5-12], coumarins [13-16] and limonoids [17]. In continuation of our investigation on the Rutaceae plants [18], we report the identification of seven compounds isolated from Clausena anisata.

\section{Results and Discussion}

The stem bark and roots of Clausena anisata were extracted with methanol. Each extract was subjected to column chromatography and TLC to yield three carbazole alkaloids and two peptide derivatives (Figure 1) identified as: girinimbine (1), murrayamine-A (2), ekeberginine (3), aurantiamide acetate (4) and $N$-benzoylphenylalaninyl- $N$-benzoylphenylalaninate (5) by spectroscopic methods and direct comparison of spectral data to those published in the literature. A mixture of sitosterol (6) and stigmasterol (7) was also isolated from both stem bark and roots.

Figure 1. The structures of seven chemical constituents isolated form Clausena anisata.<smiles>[R][R]=O</smiles><smiles></smiles><smiles>CCC(CC[C@H](C)C1CCC2C3CC=C4CC(O)CCC4(C)C3CCC21C)C(C)C</smiles><smiles>COc1cc(C=O)c(CC=C(C)C)c2c1[nH]c1ccccc12</smiles><smiles>[2H][C@H](c1ccccc1)[C@@H](NC(=O)c1ccccc1)C(=O)OC[C@@H](NC(=O)c1ccccc1)c1ccccc1</smiles><smiles>CCC(/C=C/[C@H](C)C1CCC2C3CC=C4CC(O)CCC4(C)C3CC[C@@]21C)C(C)C</smiles> 


\subsection{Isolation and $\mathrm{NMR}\left({ }^{1} \mathrm{H}\right.$ and $\left.{ }^{13} \mathrm{C}\right)$ Analysis}

Compound 1 was obtained as a colorless powder from chromatographic fractions 4-7 (5\% ethyl acetate in hexane) of stem bark extract. The solid was recrystallized from the eluting solvent to give white crystals $(143.5 \mathrm{mg})$ that had a melting point of $175-176{ }^{\circ} \mathrm{C}$. The purified compound gave a positive reaction with Dragendorff's reagent. Analysis of the ${ }^{1} \mathrm{H}-\mathrm{NMR}$ and ${ }^{1} \mathrm{H}-{ }^{1} \mathrm{H}-\mathrm{COSY}$ spectra identified a typical ABCD ring system with the benzene ring protons at $\delta 7.91(1 \mathrm{H}, \mathrm{d}, J=8 \mathrm{~Hz}, \mathrm{H}-5)$, $7.38(1 \mathrm{H}, \mathrm{d}, J=8 \mathrm{~Hz}, \mathrm{H}-8), 7.31(1 \mathrm{H}, \mathrm{t}, J=7.5 \mathrm{~Hz}, \mathrm{H}-7)$ and $7.18(1 \mathrm{H}, \mathrm{t}, J=7.5 \mathrm{~Hz}, \mathrm{H}-6)$. The broad singlet at $\delta 7.86$ indicated the presence of $\mathrm{N}-\mathrm{H}$; the resonances observed at $\delta 6.63(1 \mathrm{H}, \mathrm{d}, J=9.5 \mathrm{~Hz}$, $\mathrm{H}-9), 5.70(1 \mathrm{H}, \mathrm{d}, J=9.5 \mathrm{~Hz}, \mathrm{H}-10), 1.56(3 \mathrm{H}, \mathrm{s}, 12-\mathrm{Me})$ and $1.49(3 \mathrm{H}, \mathrm{s}, 13-\mathrm{Me})$ indicated the presence of a chromene ring in the structure. The chromene ring is confirmed by ${ }^{13} \mathrm{C}-\mathrm{NMR}$ resonances at $\delta 149.9$ (C-2), 129.6 (C-10), 117.4 (C-9), 76.0 (C-11), 27.7 (C-13) and 27.7 (C-12). These data and the distinctive UV spectrum were compared with those of 3,3,5-trimethyl-11H-pyrano[3,2-a]carbazole, confirming the structure of $\mathbf{1}$ as that of the known alkaloid girinimbine, previously isolated from Murraya koenigii [19,20] and Murraya euchrestifolia [21].

Compound 2 was obtained as white crystals from chromatographic fractions $8-11(10 \%$ ethyl acetate in hexane) of stem bark extract. The solid was purified by crystallization from the eluting solvent, yielding a mass of $4.5 \mathrm{mg}$ that melted at $166-167{ }^{\circ} \mathrm{C}$. The purified compound gave positive reactions with Draggendorff's reagent and ferric chloride, the latter indicating the presence of a phenolic function in the structure. The analysis of ${ }^{1} \mathrm{H}-\mathrm{NMR}$ and ${ }^{1} \mathrm{H}-{ }^{1} \mathrm{H}-\mathrm{COSY}$ spectra identified an ABX mutually coupled proton system at $\delta 7.75(1 \mathrm{H}, \mathrm{d}, J=8 \mathrm{~Hz}, \mathrm{H}-5), 6.87(1 \mathrm{H}, \mathrm{d}, J=2 \mathrm{~Hz}, \mathrm{H}-8)$ and 6.69 $(1 \mathrm{H}, \mathrm{dd}, J=8,2 \mathrm{~Hz}, \mathrm{H}-6)$. The broad singlet at $\delta 7.86$ indicated the presence of $\mathrm{N}-\mathrm{H}$ in the structure. The two three-proton singlets at $\delta 1.56(3 \mathrm{H}, \mathrm{s}, 12-\mathrm{Me})$ and $1.49(3 \mathrm{H}, \mathrm{s}, 13-\mathrm{Me})$ together with AB type signals at $\delta 6.63$ and 5.70 (each $1 \mathrm{H}, \mathrm{d}, J=10 \mathrm{~Hz}, \mathrm{H}-9$ and $\mathrm{H}-10$ ) revealed the presence of a 2,2-dimethylpyran ring in the molecule. A downfield shift singlet at $\delta 7.67(1 \mathrm{H})$, together with a three-proton singlet at $\delta 2.33$ is due to $\mathrm{H}-4$ and $3-\mathrm{Me}$ of the carbazole skeleton. The presence of a 2,2-dimethylpyran ring was confirmed by ${ }^{13} \mathrm{C}-\mathrm{NMR}$ chemical shifts at $\delta 151.2$ (C-2), 129.8 (C-10), 117.4 (C-9), 76.0 (C-11), 27.7 (C-13) and 27.7 (C-12) and characteristic UV absorbances. These data, are identical to those in the literature for murrayamine-A, a carbazole alkaloid isolated from Murraya euchrestifolia by $\mathrm{Wu}[22]$.

Compound 3, isolated as a brown powder $\left(63.2 \mathrm{mg}\right.$, m.p. $\left.227-228{ }^{\circ} \mathrm{C}\right)$ from fractions $30-33(15 \%$ ethyl acetate in hexane) of stem bark extract, gave a yellow colour with Dragendorff's reagent. The ${ }^{1} \mathrm{H}-\mathrm{NMR}$ spectral data of this alkaloid showed signals for an $\mathrm{NH}(\delta 8.65$, br s), an aldehyde group ( $\delta$ $10.46, \mathrm{~s})$, an uncoupled aromatic proton $(\delta 7.49, \mathrm{~s})$, a methoxyl group $(\delta 4.05, \mathrm{~s})$, and four aromatic protons of an ortho-disubstituted ring at $\delta 8.15$ (dd, $J=8.0,1.3 \mathrm{~Hz}, \mathrm{H}-5), \delta 7.52(\mathrm{dd}, J=8.0,1.3 \mathrm{~Hz}$, $\mathrm{H}-8), \delta 7.46(\mathrm{td}, J=8.0,1.3 \mathrm{~Hz}, \mathrm{H}-7)$ and $\delta 7.30(\mathrm{td}, J=8.0,1.3 \mathrm{~Hz}, \mathrm{H}-6)$, typical of a 3-formyl carbazole alkaloid [23]. The UV spectrum of 3 also was a close match to that of 3-formylcarbazole [12]. The arrangement of the aromatic protons in this ABCD ring system was confirmed by the ${ }^{1} \mathrm{H}-{ }^{1} \mathrm{H}$ COSY spectrum, which showed correlations of H-6 with H-5 and H-7, and H-7 with H-8. The ${ }^{1} \mathrm{H}-\mathrm{NMR}$ spectrum also displayed two olefinic methyl groups ( $\delta 1.91 \mathrm{br} \mathrm{s}$ and $1.70 \mathrm{br} \mathrm{s}$ ), a vinyl proton 
$(\delta 5.33, \mathrm{t}, J=6.5 \mathrm{~Hz})$ and benzylic methylene protons $(\delta 4.32, \mathrm{~d}, J=6.5 \mathrm{~Hz})$, indicating the presence of a prenyl group in the molecule. The ${ }^{13} \mathrm{C}$-NMR and ${ }^{13} \mathrm{C}$-DEPT135 spectra provided evidence that compound 3 possessed an aldehyde $\left(\delta_{\mathrm{C}} 190.6\right)$, a methoxyl group $\left(\delta_{\mathrm{C}} 55.9\right)$, two methyls $\left(\delta_{\mathrm{C}} 25.8\right.$ and 18.5), a benzylic methylene $\left(\delta_{\mathrm{C}} 27.0\right)$, six methines, and eight quaternary carbons. Based on the spectral evidence, the structure of compound 3 was assigned as 1-methoxy-3-formyl-4-(3'-methylbut2-enyl)carbazole, an alkaloid isolated previously from Ekebergia senegalensis by Lontsi et al. and named ekeberginine [24].

Compound 4 was isolated as white crystals $\left(4.1 \mathrm{mg}\right.$, m.p. $\left.183-184{ }^{\circ} \mathrm{C}\right)$ from fractions $58-61$ of root extract. Analysis of the ${ }^{1} \mathrm{H}-\mathrm{NMR}$ and ${ }^{1} \mathrm{H}-{ }^{1} \mathrm{H}$ COSY spectra of this compound identified two ABX coupling systems: $\delta 4.79(1 \mathrm{H}, \mathrm{q}, J=5.6 \mathrm{~Hz}, \mathrm{H}-13), \delta 3.25(1 \mathrm{H}, \mathrm{dd}, J=13.3,6.3 \mathrm{~Hz}, \mathrm{H}-21 \mathrm{~b})$ and $\delta 3.08$ $(1 \mathrm{H}, \mathrm{dd}, J=13.3,8.4 \mathrm{~Hz}, \mathrm{H}-21 \mathrm{a})$; and $\delta 4.37(1 \mathrm{H}$, dddd, $J=8.4,7,4.9,4.2 \mathrm{~Hz}, \mathrm{H}-2), \delta 3.95(1 \mathrm{H}$, dd, $J=11.9,4.9 \mathrm{~Hz}, \mathrm{H}-10 \mathrm{~b})$ and $\delta 3.83(1 \mathrm{H}, \mathrm{dd}, J=11.9,4.2 \mathrm{~Hz}, \mathrm{H}-10 \mathrm{a})$. A correlation between the proton at $\delta 4.79(1 \mathrm{H}, \mathrm{q}, J=5.6 \mathrm{~Hz}, \mathrm{H}-13)$ and an $\mathrm{NH}$ group at $\delta 6.76(1 \mathrm{H}, \mathrm{d}, J=7.7 \mathrm{~Hz}, \mathrm{~N}-\mathrm{Hb})$ was observed. Also, the proton at $\delta 4.37(1 \mathrm{H}$, dddd, $J=8.4,7,4.9,4.2 \mathrm{~Hz}, \mathrm{H}-2)$ correlated with two other groups of protons at $\delta 2.77(2 \mathrm{H}, \mathrm{m})$ and $\delta 5.95(1 \mathrm{H}, \mathrm{d}, J=8.4 \mathrm{~Hz}, \mathrm{~N}-\mathrm{Ha})$. Analysis of the aromatic proton regions of the ${ }^{1} \mathrm{H}-\mathrm{NMR}$ and ${ }^{1} \mathrm{H}-{ }^{1} \mathrm{H}-\mathrm{COSY}$ spectra revealed the presence of three AA'BB' $\mathrm{C}$ coupling systems, each corresponding to a monosubstituted benzene nucleus. The ${ }^{13} \mathrm{C}-\mathrm{NMR}$ and ${ }^{13} \mathrm{C}$-DEPT135 spectra provided evidence that compound $\mathbf{4}$ has two amide functions $\left(\delta_{\mathrm{C}} 171.2\right.$ and $168.1)$, an ester function $\left(\delta_{\mathrm{C}} 171.8\right)$, two benzylic methylenes $\left(\delta_{\mathrm{C}} 38.4\right.$ and 39.4$)$, an oxymethylene $\left(\delta_{\mathrm{C}}\right.$ $65.5)$, a methyl group $\left(\delta_{\mathrm{C}} 21.8\right)$, seventeen methines and three other quaternary carbons. Comparison of these data and the specific rotation with literature values led to the identification of compound $\mathbf{4}$ as a peptide derivative, aurantiamide acetate, named saropeptate by Ishiguro et al. [25]. Aurantiamide acetate (4) has been isolated previously from Aspergillus penicilloides [26], two alga species (Cystoseira corniculata [27] and Acanthospora specifera [28]), and several families of higher plants: Euphorbiaceae (Euphorbia fischeriana [29] and Croton hieronymi [30]), Piperaceae (Piper aurantiacum [31,32]), Leguminosae (Medicago polymorpha [33] and Pongamia glabra [34]), Sterculiaceae (Pterospermum heyneanum [35]), Morinagaceae (Moringa oleifera [36]), and Rutaceae (Zanthoxylum setulosum [37]).

Compound 5 was isolated as white crystals (4.6 mg, m.p. 209-210 ${ }^{\circ} \mathrm{C}$ ) from fractions $64-68$ of root extract. The analysis of spectral data revealed resonances at chemical shifts similar to those of aurantiamide acetate (4) suggesting that this compound is also a peptide derivative. The ${ }^{1} \mathrm{H}-\mathrm{NMR}$ and ${ }^{1} \mathrm{H}-{ }^{1} \mathrm{H}$ COSY spectra displayed three ABX coupling systems at $\delta 4.65(1 \mathrm{H}$, dddd, $J=8.4,7,4.2,3.5 \mathrm{~Hz}$, $\mathrm{H}-2), \delta 3.03(1 \mathrm{H}, \mathrm{dd}, J=14,7 \mathrm{~Hz}, \mathrm{H}-3 \mathrm{~b})$ and $\delta 2.92(1 \mathrm{H}, \mathrm{dd}, J=14,8.4 \mathrm{~Hz}, \mathrm{H}-3 \mathrm{a}) ; \delta 4.94(1 \mathrm{H}, \mathrm{q}$, $\left.J=7 \mathrm{~Hz}, \mathrm{H}-2^{\prime}\right), \delta 3.32\left(1 \mathrm{H}, \mathrm{dd}, J=14,6.3 \mathrm{~Hz}, \mathrm{H}-3^{\prime} \mathrm{b}\right)$ and $\delta 3.24\left(1 \mathrm{H}, \mathrm{dd}, J=14,7 \mathrm{~Hz}, \mathrm{H}-3^{\prime} \mathrm{a}\right)$; and $\delta$ $4.65(1 \mathrm{H}$, dddd, $J=8.4,7,4.2,3.5 \mathrm{~Hz}, \mathrm{H}-2), \delta 4.57(1 \mathrm{H}, \mathrm{dd}, J=11.9,3.5 \mathrm{~Hz}, \mathrm{H}-1 \mathrm{~b})$ and $\delta 4.06(1 \mathrm{H}$, $\mathrm{dd}, J=11.9,4.2 \mathrm{~Hz}, \mathrm{H}-1 \mathrm{a})$. Also, a correlation was observed between a proton at $\delta 4.65(1 \mathrm{H}$, dddd, $J=8.4,7,4.2,3.5 \mathrm{~Hz}, \mathrm{H}-2)$ and an $\mathrm{NH}$ group at $\delta 6.70(1 \mathrm{H}, \mathrm{d}, J=8.4 \mathrm{~Hz}, \mathrm{~N}-\mathrm{Hb})$. Similarly, a correlation was observed between a proton at $\delta 4.94\left(1 \mathrm{H}, \mathrm{q}, J=7, \mathrm{H}-2^{\prime}\right)$ and an $\mathrm{NH}$ group at $\delta 6.59$ $(1 \mathrm{H}, \mathrm{d}, J=6.3 \mathrm{~Hz}, \mathrm{~N}-\mathrm{Ha})$. The signals from hydrogens on aromatic rings $(\delta 7.72-7.23)$ were compatible with four monosubstituted benzene rings. Thus both compound $\mathbf{5}$ and aurantiamide acetate (4) have $N$-benzoylphenylalanine moieties as the left halves of their structures. Compound $\mathbf{5}$, however, 
was esterified to $N$-benzoylphenylalaninol, as shown by the chemical shifts of $\mathrm{H}-1, \mathrm{H}-2, \mathrm{H}-3$ and the presence of a second benzamide functionality. The ${ }^{13} \mathrm{C}-\mathrm{NMR}$ and ${ }^{13} \mathrm{C}$-DEPT135 spectra provided evidence for two amide functions ( $\delta_{\mathrm{C}} 168.4$ and 168.2), an ester function $\left(\delta_{\mathrm{C}} 172.9\right)$, two benzylic methylenes $\left(\delta_{\mathrm{C}} 38.5\right.$ and 38.3$)$, an oxymethylene $\left(\delta_{\mathrm{C}} 66.4\right)$, twenty-two methines and four quaternary carbons in the structure of compound $\mathbf{5}$. These data and the measured specific rotation are consistent with those published for $N$-benzoyl-L-phenylalaninyl- $N$-benzoyl-L-phenylalaninate, also named asperphenamate. Compound $\mathbf{5}$ has been isolated previously from fungal species: Aspergillus flavipes [38], Anaphalis subumbellata [39], and the Penicillum species P. canadense [40], P. brevicompactum [41] and P. megasporum [42]; and several families of higher plants: Euphorbiaceae (Croton hieronymi [30]), Bignognaceae (Zeyhera digitalis [43]), Piperaceae (Piper aurantiacum [32]), Leguminosaea (Medicago polymorpha [33] and Piptadenia gonoacantha [44]), and Moraceae (Artocarpus kemando [45]).

Dipeptide derivatives are rare and have not been found previously in Clausena species. Two other compounds, sitosterol 6 and stigmasterol 7, were identified by direct comparison of the chemical shifts of their ${ }^{1} \mathrm{H}$ and ${ }^{13} \mathrm{C}$-NMR resonances with data published in literature.

\subsection{Mass Spectrometry of the Isolated Compounds}

Upon electrospray ionization mass spectrometry ( ESI $(+) \mathrm{MS})$, girinimbine (1) was detected as the $[\mathrm{M}+\mathrm{H}]^{+}$ion, while all other compounds isolated formed adduct ions with sodium $\left([\mathrm{M}+\mathrm{Na}]^{+}\right)$. Murrayamine-A (2), ekeberginine (3) and aurantiamide acetate (4) also formed $[2 \mathrm{M}+\mathrm{Na}]^{+}$ions. The prominence of the sodium adducts in the mass spectra contrasts with the low abundance of sodium adducts reported in an extensive survey of the ESI(+)MS of natural products [46] and illustrates the effect of solvent (i.e., methanol vs. acetonitrile-formic acid) on ionization behavior. The prominent $[\mathrm{M}-\mathrm{H}]^{-}$ions obtained upon ESI(-)MS of girinimbine (1), murrayamine-A (2), and ekeberginine (3) most likely are formed by deprotonation at the carbazole N-H. The gas phase acidity of carbazole (ca. $1420 \mathrm{~kJ} \mathrm{~mol}^{-1}$ [47]) is greater than that of aliphatic carboxylic acids (ca. $1450 \mathrm{~kJ} \mathrm{~mol}^{-1}$ [47]), which deprotonate readily when subjected to electrospray ionization [48].

The sodium adducts of aurantiamide acetate (4) and $N$-benzoylphenylalaninyl- $N$ benzoylphenylalaninate (5) yielded distinct product ions upon collision-induced dissociation (CID). For each, rational fragmentation pathways leading to the observed product ions were consistent with the structures assigned.

CID of the $m / z 467$ ion $4 \mathbf{a}$ formed upon ionization of aurantiamide acetate (4) yielded five product ions, $m / z$ 449, 407, 385, 274 and 224. Losses of acetic acid or sodium acetate (Scheme 1) accounted for the major ions at $\mathrm{m} / \mathrm{z} 407$ (4b) and 385 (4c), respectively. CID of the $\mathrm{m} / \mathrm{z} 385$ ion (generated in-source) yielded the $m / z 224$ ion as the major fragmentation product, indicating that the $m / z 224$ ion is formed from the $m / z 467$ ion via the $m / z 385$ ion. 
Scheme 1. Major MS fragmentation of $\mathbf{4 a}$, the $[\mathrm{M}+\mathrm{Na}]^{+}$ion of aurantiamide acetate (4).<smiles>CC(=O)OCC(Cc1ccccc1)NC(=O)C(Cc1ccccc1)NC(=O)c1ccccc1</smiles>

$4 \mathrm{a}[\mathrm{M}+\mathrm{Na}]^{+} \mathrm{m} / \mathrm{z} 467$<smiles>C=C(Cc1ccccc1)NC(=O)C(Cc1ccccc1)NC(=O)c1ccccc1</smiles><smiles>C=C(Cc1ccccc1)NC(=O)C(Cc1ccccc1)NC(=O)c1ccccc1</smiles>

Formation of the $\mathrm{m} / \mathrm{z} 449$ product ion in low abundance indicated loss of water from the $\mathrm{m} / \mathrm{z} 467$ ion 4a as a minor fragmentation process. A second minor fragmentation process of the $m / z 467$ ion $4 \mathbf{a}$ led to formation of the $m / z 274$ ion $\mathbf{4 d}$ (Scheme 2). This process is consistent with cleavage of an amide bond and retention of sodium to generate the $\mathrm{m} / \mathrm{z} 274$ product ion from the $N$-benzoylphenylalanine portion of aurantiamide acetate (4).

Scheme 2. Minor MS fragmentation of $\mathbf{4 a}$, the $[\mathrm{M}+\mathrm{Na}]^{+}$ion of aurantiamide acetate (4).<smiles>CC(=O)OCC(Cc1ccccc1)NC(=O)C(Cc1ccccc1)NC(=O)c1ccccc1</smiles><smiles>C=C</smiles><smiles>[NH3+]OC(=NC(=C=O)Cc1ccccc1)c1ccccc1</smiles>

4d $m / z 274$

Product ions 5b and 5c at $\mathrm{m} / \mathrm{z} 292$ (major) and $\mathrm{m} / \mathrm{z} 260$ (minor), respectively, were observed upon CID of the $\mathrm{m} / \mathrm{z} 529$ ion $\mathbf{5 a}$, formed by ionization of $N$-benzoylphenylalaninyl- $N$-benzoylphenylalaninate (5) (Scheme 3). The sum of the masses of the two product ions (5b and 5c) equals the mass of the precursor ion 5a plus that of a sodium ion, indicating that both product ions are sodium ion adducts. Cleavage of the $\mathrm{C}-1-\mathrm{O}$ bond accompanied by transfer of $\mathrm{H}-2$ to the $\mathrm{C}-1$ ' carbonyl oxygen via a six-membered cyclic transition state accounts for the formation of both product ions from the $\mathrm{m} / \mathrm{z}$ 529 ion $\mathbf{5 a}$; the product ion observed depends on which half of ion $\mathbf{5 a}$ retains the sodium ion. 
Scheme 3. MS fragmentation of 5a, the $[\mathrm{M}+\mathrm{Na}]^{+}$ion of $\mathrm{N}$-benzoylphenylalaninyl- $\mathrm{N}$ benzoylphenylalaninate (5).

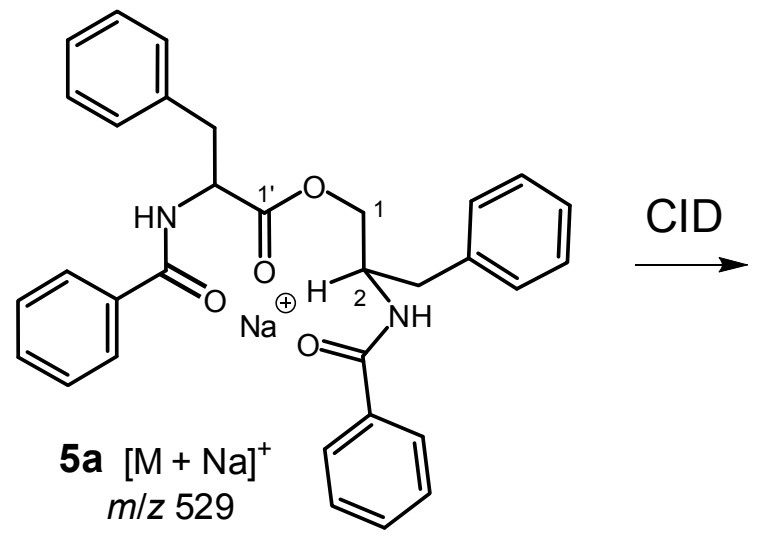

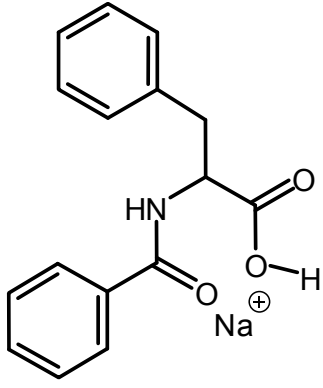

5b $\mathrm{m} / \mathrm{z} 292$ (major)

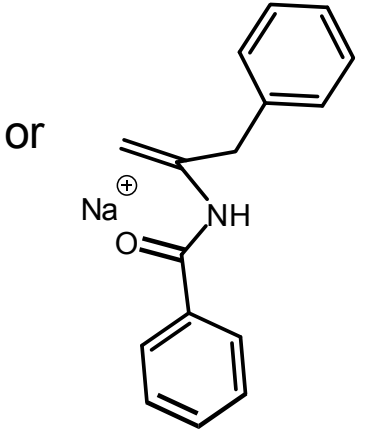

5c $\mathrm{m} / \mathrm{z} 260$ (minor)

\subsection{Biosynthesis and Biological Activity}

In higher plants, shikimic acid, malonyl-CoA and prenyl phosphate are proposed as the primary biosynthetic precursors of 3-methylcarbazole, an advanced precursor that undergoes oxygenation and prenylation [49] to yield the more highly substituted carbazole alkaloids found in Clausena species [5-12] and other plants [49]. With a one-carbon substituent at C-3, the structures of girinimbine (1), murrayamine-A (2) and ekeberginine (3) are consistent with this biogenetic hypothesis.

Previously, several different biological activities have been recognized for compounds 1-5. Cytotoxicity, antitumor activity and induction of apoptosis have been assessed for compounds 1 [6,50-53], 2 [22], 3 [9] and 5 [54,55], while girinimbine (1) also exhibited antimicrobial activity [56], anti-trichomonal activity [57] and cyclooxygenase inhibition [58]. Murrayamine-A (2) and aurantiamide acetate (4) display antiplatelet aggregation activity [59] and anti-inflammatory properties [36,60], respectively. The enzymes cathepsin [26] and $\alpha$-glucosidase [61] are inhibited by $\mathbf{4}$, whereas 5 is a weak inhibitor of aromatase [62]. Overall, the role of Clausena anisata in traditional medicine [2,3] is supported, at least in part, by the biological activities of the alkaloids and peptide derivatives isolated from its stem bark and roots.

\section{Experimental}

\subsection{General}

Melting points (uncorrected) were determined on a Gallenkamp melting point apparatus in open capillary tubes. Mass spectra were obtained by electrospray ionization on a Bruker microTOF (accurate mass measurements) and Thermo-Finningan LCQ Duo (tandem mass spectra) mass spectrometers using flow injection in methanol [48]. Collision-induced dissociation (CID) energies are given in parentheses in the arbitrary units (\%) supplied by the software. NMR spectra (both $1 \mathrm{D}$ and 2D) were acquired on a Bruker AVANCE $500 \mathrm{MHz}$ spectrometer $\left(500.13 \mathrm{MHz}\right.$ for ${ }^{1} \mathrm{H}$ and 125.76 MHz for ${ }^{13} \mathrm{C}$ ) and a Bruker AV-III $700 \mathrm{MHz}$ spectrometer $\left(700.23 \mathrm{MHz}\right.$ for ${ }^{1} \mathrm{H}$ and $176.09 \mathrm{MHz}$ for $\left.{ }^{13} \mathrm{C}\right)$ equipped with a 5 -mm TCI cryoprobe. Chemical shifts $(\delta, \mathrm{ppm})$ are reported relative to TMS 
as internal standard, and coupling constants $(J)$ are given in Hz. Methyl, methylene and methine carbons were distinguished by DEPT experiments. UV spectra were collected in methanol on an Agilent 8345 spectrophotometer, and optical rotations were measured using a Rudolph Instruments Digipol 781 automatic polarimeter. Column chromatography was performed on silica gel (70-230 mesh, $60 \AA$ ) using hexane, hexane-ethyl acetate and ethyl acetate as eluents. PTLC was carried out using Merck Si gel $60 \mathrm{GF}_{254}$ on glass plates $(20 \times 20 \mathrm{~cm})$ at a thickness of $0.5 \mathrm{~mm}$. TLC was carried out on Sigma-Aldrich TLC plates, Si gel matrix with fluorescent indicator. Spots on TLC and PTLC plates were visualized under UV light (254 and $366 \mathrm{~nm})$ and by spraying with Dragendorff's reagent and/or aqueous sulfuric acid (10\%).

\subsection{Plant Material}

The stem bark and roots of Clausena anisata were collected from Limbe, south west region, Cameroon, in August 2009. The plant was identified by M. Litonga Ndive Elias, taxonomist at Botanic Garden of Limbe, Cameroon, where the voucher specimen has been deposited.

\subsection{Extraction and Isolation}

Air dried plants $(2.4 \mathrm{~kg}$ of stem bark and $3.1 \mathrm{~kg}$ of roots) were ground to a fine powder and extracted twice with methanol $(2 \times 10 \mathrm{~L}, 4$ days $)$ at ambient temperature. The stem bark and root extracts were concentrated under reduced pressure to yield dark brown viscous syrups (39 and $35 \mathrm{~g}$, respectively). Each crude extract was subjected to column vacuum chromatography over silica gel and eluted with mixtures of hexane, ethyl acetate and methanol, in order of increasing polarities to give about 110 fractions each. Work up procedures on the fractions afforded three carbazole alkaloids (compounds 1, 2 and 3), two peptide derivatives (compounds 4 and 5), and two phytosterols 6 and 7 , which were identified using spectroscopic methods (1D and 2D-NMR, MS).

Fractions 4-7 (crude methanol extract of stem bark; eluent: hexane/ethyl acetate/methanol) were combined to give girinimbine $\left(1,143.5 \mathrm{mg}\right.$ ) as a colorless powder, $\mathrm{C}_{18} \mathrm{H}_{17} \mathrm{NO}$, m.p. $175-176{ }^{\circ} \mathrm{C}$ (lit. 175-177 $\left.{ }^{\circ} \mathrm{C}[19]\right) . \mathrm{UV} \lambda_{\max } \mathrm{nm}(\log \varepsilon): 237$ (4.64), 277sh (4.34), 287 (4.57), 327 (3.88), 342 (3.88), 358 (3.82). ${ }^{1} \mathrm{H}-\mathrm{NMR}\left(500 \mathrm{MHz}, \mathrm{CDCl}_{3}\right) \delta: 7.91(1 \mathrm{H}, \mathrm{d}, J=8 \mathrm{~Hz}, \mathrm{H}-5), 7.86(1 \mathrm{H}$, br s, N-H), $7.67(1 \mathrm{H}$, s, H-4), $7.38(1 \mathrm{H}, \mathrm{d}, J=8 \mathrm{~Hz}, \mathrm{H}-8), 7.31(1 \mathrm{H}, \mathrm{t}, J=7.5 \mathrm{~Hz}, \mathrm{H}-7), 7.18(1 \mathrm{H}, \mathrm{t}, J=7.5 \mathrm{~Hz}, \mathrm{H}-6), 6.63$ $(1 \mathrm{H}, \mathrm{d}, J=9.5 \mathrm{~Hz}, \mathrm{H}-9), 5.70(1 \mathrm{H}, \mathrm{d}, J=9.5 \mathrm{~Hz}, \mathrm{H}-10), 2.33(3 \mathrm{H}, \mathrm{s}, 14-\mathrm{Me}), 1.56$ (3H, s, 12-Me), 1.49 (3H, s, 13-Me). ${ }^{13} \mathrm{C}-\mathrm{NMR}\left(126 \mathrm{MHz}, \mathrm{CDCl}_{3}\right) \delta$ : 149.9 (C-2), 139.9 (C-1a), 134.9 (C-8a), 129.6 (C-10), 124.4 (C-7), 124.0 (C-3), 121.4 (C-4), 119.6 (C-6), 119.4 (C-5), 118.8 (C-5a), 117.4 (C-9), 116.9 (C-4a), 110.5 (C-8), 104.6 (C-1), 76.0 (C-11), 27.7 (C-12), 27.7 (C-13), 16.2 (C-14). ESI(+)MS (relative intensity): $m / z 264[\mathrm{M}+\mathrm{H}]^{+}$; MS/MS (CID 33\%) of $m / z$ 264: $m / z 249$ (55), 246 (18), 236 (100), 222 (65); ESI(+)TOF-MS $m / z$ 264.1394 [M+H] ${ }^{+}$(264.1383, calculated for $\mathrm{C}_{18} \mathrm{H}_{18} \mathrm{NO}$ ). ESI(-)MS (relative intensity): $\mathrm{m} / z 262[\mathrm{M}-\mathrm{H}]^{-}$; MS/MS (CID 38\%) of $\mathrm{m} / \mathrm{z} 262: \mathrm{m} / \mathrm{z} 279$ (20), 247 (100), 246 (80); ESI(-)TOF-MS $m / z 262.1233$ [M-H] $]^{-}$(262.1237, calculated for $\mathrm{C}_{18} \mathrm{H}_{16} \mathrm{NO}$ ).

Fractions 8-11 (crude methanol extract of stem bark; eluent: hexane/ethyl acetate/methanol) were combined to give murrayamine-A (2, $4.5 \mathrm{mg})$ as white crystals, $\mathrm{C}_{18} \mathrm{H}_{17} \mathrm{NO}_{2}$, m.p. $166-167{ }^{\circ} \mathrm{C}$ (lit. 
162-163 $\left.{ }^{\circ} \mathrm{C}[22]\right) . \mathrm{UV} \lambda_{\max } \mathrm{nm}(\log \varepsilon): 222 \mathrm{sh}$ (4.24), 236 (4.35), 278sh (4.12), 287 (4.28), 328 (3.62), 342 (3.64), 357 (3.56). ${ }^{1} \mathrm{H}-\mathrm{NMR}\left(500 \mathrm{MHz}, \mathrm{CDCl}_{3}\right) \delta: 7.86(1 \mathrm{H}$, br s, N-H), $7.75(1 \mathrm{H}, \mathrm{d}, J=8 \mathrm{~Hz}$, H-5), 7.67 (1H, s, H-4), 6.87 (1H, d, $J=8 \mathrm{~Hz}, \mathrm{H}-8), 6.69$ (1H, dd, $J=8,2 \mathrm{~Hz}, \mathrm{H}-6), 6.63$ (1H, d, $J=10 \mathrm{~Hz}, \mathrm{H}-9), 5.70$ (1H, d, $J=10 \mathrm{~Hz}, \mathrm{H}-10), 2.33(3 \mathrm{H}, \mathrm{s}, 14-\mathrm{Me}), 1.56(3 \mathrm{H}, \mathrm{s}, 12-\mathrm{Me}), 1.49$ (3H, s, 13-Me). ${ }^{13} \mathrm{C}-\mathrm{NMR}\left(126 \mathrm{MHz}, \mathrm{CDCl}_{3}\right.$ ) $\delta: 152.0$ (C-7), 151.2 (C-2), 141.1 (C-8a), 139.5 (C-1a), 129.8 (C-10), 124.0 (C-3), 121.1 (C-4), 119.4 (C-5), 118.0 (C-5a), 117.4 (C-9), 115.9 (C-4a), 110.6 (C-6), 106.2 (C-1), 102.5 (C-8), 76.0 (C-11), 27.7 (C-12), 27.7 (C-13), 16.2 (C-14). ESI(+)MS (relative intensity): $m / z 581$ (98) $[2 \mathrm{M}+\mathrm{Na}]^{+}, 302(100)[\mathrm{M}+\mathrm{Na}]^{+}$; ESI(+)TOF-MS $m / z 581.2341[2 \mathrm{M}+\mathrm{Na}]^{+}$ (581.2411, calculated for $\mathrm{C}_{36} \mathrm{H}_{34} \mathrm{~N}_{2} \mathrm{O}_{4} \mathrm{Na}$ ), $302.1120[\mathrm{M}+\mathrm{Na}]^{+}$(302.1151, calculated for $\mathrm{C}_{18} \mathrm{H}_{17} \mathrm{NO}_{2} \mathrm{Na}$ ). ESI(-)MS (relative intensity): $\mathrm{m} / \mathrm{z} 278$ [M-H] ; MS/MS (CID 36\%) of $\mathrm{m} / \mathrm{z} 278: \mathrm{m} / \mathrm{z} 250$ (25), 223 (100), 222 (20); ESI(-)TOF-MS $m / z 278.1173$ [M-H] $]^{-}$(278.1187, calculated for $\mathrm{C}_{18} \mathrm{H}_{16} \mathrm{NO}_{2}$ ).

Fractions 30-33 (crude methanol extract stem bark; eluent: hexane/ethyl acetate/methanol) were combined to give ekeberginine (3, $63.2 \mathrm{mg}$ ) as a brown powder, $\mathrm{C}_{19} \mathrm{H}_{19} \mathrm{NO}_{2}$, m.p. $227-228{ }^{\circ} \mathrm{C}$ (lit. 230-231 ${ }^{\circ} \mathrm{C}$ [24]). UV $\lambda_{\max } \mathrm{nm}(\log \varepsilon): 240$ (4.35), 251sh (4.25), 274 (4.39), 287 (4.27), 343 (3.99). ${ }^{1} \mathrm{H}-\mathrm{NMR}\left(500 \mathrm{MHz}, \mathrm{CDCl}_{3}\right) \delta: 10.46(1 \mathrm{H}, \mathrm{s}, 3-\mathrm{CHO}), 8.65(1 \mathrm{H}, \mathrm{br} \mathrm{s}, \mathrm{N}-\mathrm{H}), 8.15(1 \mathrm{H}, \mathrm{dd}, J=8.0,1.3$ Hz, H-5), 7.52 (1H, dd, $J=8,1.3 \mathrm{~Hz}, \mathrm{H}-8), 7.49(1 \mathrm{H}, \mathrm{s}, \mathrm{H}-2), 7.46(1 \mathrm{H}, \mathrm{td}, J=8.0,1.3 \mathrm{~Hz}, \mathrm{H}-7), 7.30$ $(1 \mathrm{H}, \mathrm{td}, J=8.0,1.3 \mathrm{~Hz}, \mathrm{H}-6), 5.33\left(1 \mathrm{H}, \mathrm{t}, J=6.5 \mathrm{~Hz}, \mathrm{H}-2^{\prime}\right), 4.32\left(2 \mathrm{H}, \mathrm{t}, J=6.5 \mathrm{~Hz}, \mathrm{H}-1^{\prime}\right), 4.05(3 \mathrm{H}, \mathrm{s}$, 1-OMe), 1.91 (3H, s, 5'-Me), $1.70\left(3 \mathrm{H}, \mathrm{s}, 4^{\prime}-\mathrm{Me}\right) .{ }^{13} \mathrm{C}-\mathrm{NMR}\left(126 \mathrm{MHz}, \mathrm{CDCl}_{3}\right) \delta$ : 190.6 (3-CHO), 144.2 (C-1), 139.6 (C-8a), 136.7 (C-1a), 134.6 (C-4), 132.9 (C-3'), 126.6 (C-3), 126.1 (C-7), 123.9 (C-4a), 123.2 (C-5), 122.7 (C-5a), 122.4 (C-2'), 120.8 (C-6), 111.5 (C-8), 104.7 (C-2), 55.9 (1-OMe), $27.0\left(\mathrm{C}-1^{\prime}\right), 25.8\left(\mathrm{C}-4^{\prime}\right), 18.5\left(\mathrm{C}-5^{\prime}\right)$. ESI(+)MS (relative intensity): $m / z 609$ (76) [2M+Na] $]^{+}, 316(100)$ $[\mathrm{M}+\mathrm{Na}]^{+} ; \mathrm{MS} / \mathrm{MS}$ (CID 24\%) of $\mathrm{m} / z$ 316: $\mathrm{m} / \mathrm{z}$ 298; ESI(+)TOF-MS $\mathrm{m} / \mathrm{z} 609.2694$ [2M+Na] (609.2724, calculated for $\mathrm{C}_{38} \mathrm{H}_{38} \mathrm{~N}_{2} \mathrm{O}_{4} \mathrm{Na}$ ), $316.1293[\mathrm{M}+\mathrm{Na}]^{+}$(316.1308, calculated for $\mathrm{C}_{19} \mathrm{H}_{19} \mathrm{NO}_{2} \mathrm{Na}$ ). ESI(-)MS (relative intensity): $\mathrm{m} / \mathrm{z} 292$ (100) [M-H], 277 (56); MS/MS (CID 30\%) of $\mathrm{m} / \mathrm{z}$ 292: $\mathrm{m} / \mathrm{z}$ 277; MS/MS (CID 30\%) of $\mathrm{m} / z$ 277: $\mathrm{m} / \mathrm{z} 262$ (38), 260 (14), 249 (72), 248 (30), 234 (100); ESI(-)TOF-MS $m / z 292.1330[\mathrm{M}-\mathrm{H}]^{-}\left(292.1343\right.$, calculated for $\mathrm{C}_{19} \mathrm{H}_{18} \mathrm{NO}_{2}$ ).

Fractions 58-61 (crude methanol extract roots) (eluent: hexane/ethyl acetate/methanol) were combined to give aurantiamide acetate $(4,4.1 \mathrm{mg})$ as white crystals, $\mathrm{C}_{27} \mathrm{H}_{28} \mathrm{~N}_{2} \mathrm{O}_{4}$, m.p. $183-184{ }^{\circ} \mathrm{C}$ (lit. $\left.184{ }^{\circ} \mathrm{C}[25]\right) .[\alpha]_{D}^{21}=-34.3^{\circ}\left(\mathrm{CHCl}_{3}, \mathrm{c}=0.14\right)\left(\right.$ lit. $-38.8^{\circ}\left(\mathrm{CHCl}_{3}, \mathrm{c}=0.041\right)$ [25]) ${ }^{1} \mathrm{H}-\mathrm{NMR}$ $\left(700 \mathrm{MHz}, \mathrm{CDCl}_{3}\right) \delta: 7.74(2 \mathrm{H}, \mathrm{d}, J=7.7 \mathrm{~Hz}, \mathrm{H}-16 / \mathrm{H}-20), 7.55(1 \mathrm{H}, \mathrm{t}, J=7.7 \mathrm{~Hz}, \mathrm{H}-18), 7.47(2 \mathrm{H}, \mathrm{t}$, $J=7.7 \mathrm{~Hz}, \mathrm{H}-17 / \mathrm{H}-19), 7.31$ (2H, d, $J=7 \mathrm{~Hz}, \mathrm{H}-23 / \mathrm{H}-27), 7.28$ (2H, d, $J=7 \mathrm{~Hz}, \mathrm{H}-24 / \mathrm{H}-26), 7.25$ $(1 \mathrm{H}, \mathrm{t}, J=7 \mathrm{~Hz}, \mathrm{H}-25), 7.20$ (2H, d, $J=7 \mathrm{~Hz}, \mathrm{H}-5 / \mathrm{H}-9), 7.16$ (1H, t, $J=7 \mathrm{~Hz}, \mathrm{H}-7), 7.09$ (2H, d, $J=7 \mathrm{~Hz}$, $\mathrm{H}-6 / \mathrm{H}-8), 6.76(1 \mathrm{H}, \mathrm{d}, J=7.7 \mathrm{~Hz}, \mathrm{~N}-\mathrm{Hb}), 5.95(1 \mathrm{H}, \mathrm{d}, J=8.4 \mathrm{~Hz}, \mathrm{~N}-\mathrm{Ha}), 4.79(1 \mathrm{H}, \mathrm{q}, J=5.6 \mathrm{~Hz}$, H-13), 4.37 (1H, dddd, $J=8.4,7,4.9,4.2 \mathrm{~Hz}, \mathrm{H}-2), 3.95$ (1H, dd, $J=11.9,4.9 \mathrm{~Hz}, \mathrm{H}-10 \mathrm{~b}), 3.83(1 \mathrm{H}$, dd, $J=11.9,4.2 \mathrm{~Hz}, \mathrm{H}-10 \mathrm{a}), 3.25(1 \mathrm{H}, \mathrm{dd}, J=13.3,6.3 \mathrm{~Hz}, \mathrm{H}-21 \mathrm{~b}), 3.08$ (1H, dd, $J=13.3,8.4 \mathrm{~Hz}$, H-21a), 2.80 (1H, dd, $J=13.3,8.4 \mathrm{~Hz}, \mathrm{H}-3 \mathrm{~b}), 2.77$ (1H, dd, $J=13.3,7 \mathrm{~Hz}, \mathrm{H}-3 \mathrm{a}), 2.05$ (3H, s, H-12). ${ }^{13} \mathrm{C}-\mathrm{NMR}\left(176 \mathrm{MHz}, \mathrm{CDCl}_{3}\right.$ ) $\delta: 171.8$ (s, C-11, ester), 171.2 (s, C-1, amide), 168.1 (s, C-14, amide), 137.7 (s, C-22), 134.6 (s, C-15), 137.6 (s, C-4), 132.9 (d, C-18), 130.3 (d, C-24/C-26), 130.1 (d, C-23/C-27), 129.8 (d, C-6/C-8), 129.7 (d, C-5/C-9), 129.6 (d, C-17/C-19), 128.2 (d, C-25), 128.0 (d, C-16/C-20), 127.8 (d, C-7), 65.5 (t, C-10), 55.9 (d, C-13), 50.4 (d, C-2), 39.4 (t, C-21), 38.4 (t, C-3), 
21.8 (q, C-12). ESI(+)MS (relative intensity): $m / z 911$ (12) [2M+Na] $]^{+}, 467$ (100) [M+Na] $]^{+}$MS/MS (CID 31\%) of $m / z$ 467: $\mathrm{m} / z 449$ (10), 407 (100), 385 (62), 274 (8), 224 (4); ESI(+)TOF-MS $m / z$ $467.1936[\mathrm{M}+\mathrm{Na}]^{+}\left(467.1941\right.$, calculated for $\left.\mathrm{C}_{27} \mathrm{H}_{28} \mathrm{~N}_{2} \mathrm{O}_{4} \mathrm{Na}\right)$.

Fractions 64-68 (crude methanol extract roots; eluent: hexane/ethyl acetate/methanol) were combined to give $N$-benzoyl-L-phenylalaninyl- $N$-benzoyl-L-phenylalaninate $(\mathbf{5}, 4.6 \mathrm{mg})$ as white crystals, $\mathrm{C}_{32} \mathrm{H}_{30} \mathrm{~N}_{2} \mathrm{O}_{4}$, m.p. $209-210{ }^{\circ} \mathrm{C}$ (lit. 212.5-213 ${ }^{\circ} \mathrm{C}[30]$ ). $[\alpha]_{D}^{22}=-73.5^{\circ}\left(\mathrm{EtOH}, \mathrm{c}=0.11\right.$ ) (lit. $-78.7^{\circ}$ $(\mathrm{EtOH}, \mathrm{c}=0.14)[40]) .{ }^{1} \mathrm{H}-\mathrm{NMR}\left(700 \mathrm{MHz}, \mathrm{CDCl}_{3}\right) \delta: 7.72\left(2 \mathrm{H}, \mathrm{dd}, J=7.7,1.4 \mathrm{~Hz}, \mathrm{H}-12^{\prime} / \mathrm{H}-16^{\prime}\right)$, 7.69 (2H, dd, $J=7.7,1.4 \mathrm{~Hz}, \mathrm{H}-12 / \mathrm{H}-16), 7.53(1 \mathrm{H}, \mathrm{tt}, J=7.7,1.4 \mathrm{~Hz}, \mathrm{H}-14), 7.46(1 \mathrm{H}, \mathrm{tt}, J=7.7,1.4$ Hz, H-14'), 7.42 (2H, td, $J=7.7,1.4 \mathrm{~Hz}, \mathrm{H}-13 / \mathrm{H}-15), 7.34$ (2H, td, $\left.J=7.7,1.4 \mathrm{~Hz}, \mathrm{H}-13^{\prime} / \mathrm{H}-15^{\prime}\right)$, 7.23-7.28 $(10 \mathrm{H}$, aromatic protons on two phenyl rings), $6.70(1 \mathrm{H}, \mathrm{d}, J=8.4 \mathrm{~Hz}, \mathrm{~N}-\mathrm{Hb}), 6.59(1 \mathrm{H}, \mathrm{d}$, $J=6.3 \mathrm{~Hz}, \mathrm{~N}-\mathrm{Ha}), 4.94\left(1 \mathrm{H}, \mathrm{q}, J=7 \mathrm{~Hz}, \mathrm{H}-2^{\prime}\right), 4.65$ (1H, dddd, $\left.J=8.4,7,4.2,3.5 \mathrm{~Hz}, \mathrm{H}-2\right), 4.57(1 \mathrm{H}$, dd, $J=11.9,3.5 \mathrm{~Hz}, \mathrm{H}-1 \mathrm{~b}), 4.06$ (1H, dd, $J=11.9,4.2 \mathrm{~Hz}, \mathrm{H}-1 \mathrm{a}), 3.32$ (1H, dd, $J=14,6.3 \mathrm{~Hz}, \mathrm{H}-3$ 'b), 3.24 (1H, dd, $\left.J=14,7 \mathrm{~Hz}, \mathrm{H}-3{ }^{\prime} \mathrm{a}\right), 3.03$ (1H, dd, $\left.J=14,7 \mathrm{~Hz}, \mathrm{H}-3 \mathrm{~b}\right), 2.92(1 \mathrm{H}, \mathrm{dd}, J=14,8.4 \mathrm{~Hz}$, $\mathrm{H}-3 \mathrm{a}) .{ }^{13} \mathrm{C}-\mathrm{NMR}\left(176 \mathrm{MHz}, \mathrm{CDCl}_{3}\right) \delta: 172.9$ (s, C-1'; ester $\mathrm{C}=\mathrm{O}$ ), 168.4 and 168.2 (both s, C-10 and C-10'; benzamide C=O), 138.2 (s, C-4), 136.8 (s, C-4'), 135.2 (s, C-11) 134.3 (s, C-11'), 133.0 (d, C-14), 132.4 (d, C-14'), 130.3 (d, C-5/C-9), 130.2 (d, C-5'/C-9'), 129.9 (d, C-13/C-15), 129.7 (d, C-6'/C-8'), 129.7 (d, C-6/C-8), 129.4 (d, C-13'/C-15'), 128.4 (d, C-7'), 128.1 (d, C-12'/C-16'), 128.1 (d, C-12/C-16), 127.8 (d, C-7), 66.4 (t, C-1), 55.5 (d, C-2'), 51.3 (d, C-2), 38.5 (t, C-3'), 38.3 (t, C-3). ESI(+)MS (relative intensity): $\mathrm{m} / z 529$ [M+Na] ${ }^{+}$; MS/MS (CID 28\%) of $\mathrm{m} / z$ 529: $\mathrm{m} / z 292$ (100), 260 (10); ESI(+)TOF-MS $m / z 529.2102[\mathrm{M}+\mathrm{Na}]^{+}$(529.2098, calculated for $\mathrm{C}_{32} \mathrm{H}_{30} \mathrm{~N}_{2} \mathrm{O}_{4} \mathrm{Na}$ ).

\section{Conclusions}

Three carbazole alkaloids [girinimbine (1), murrayamine-A (2) and ekeberginine (3)], two peptide derivatives [aurantiamide acetate (4) and $N$-benzoyl-L-phenylalaninyl- $N$-benzoyl-L-phenylalaninate (5)] and a mixture of sitosterol (6) and stigmasterol (7) were isolated from the stem bark and roots of the tropical shrub Clausena anisata. Compounds 1-5 have known biological activities, and 2, 4 and 5 have not been found previously as constituents of Clausena anisata.

\section{Acknowledgments}

The authors gratefully acknowledge financial support from the Canadian Commonwealth Exchange Program (sponsor of the scientific stay of JLS in the Department of Chemistry, Dalhousie University) and the Natural Science and Engineering Research Council (NSERC) of Canada (grant to RLW). We thank the Maritime Mass Spectrometry Laboratory and Nuclear Magnetic Resonance Research Resource (NMR-3) for providing facilities to acquire spectra; we are indebted to Dr. M. Lumsden for the $700 \mathrm{MHz}$ NMR spectra and X. Feng for the accurate mass measurements. The NMR data at $700 \mathrm{MHz}$ were collected at the Biomolecular Magnetic Resonance Facility (BMRF) housed in the National Research Council of Canada's Institute for Marine Biosciences. The cryoprobe was provided by Dalhousie University through an Atlantic Canada Opportunities Agency Grant. 


\section{References}

1. Letouzey, R. Flore du Gabon, Volume 6: Rutaceae, Zygophyllaceae, Balanitaceae; Muséum National d'Histoire Naturelle: Paris, France, 1963.

2. Hamza, O.J.M.; van den Bout-van den Beukel, C.J.P.; Matee, M.I.N.; Moshi, M.J.; Mikx, F.H.M.; Selemani, H.O.; Mbwambo, Z.H.; Van der Ven, A.J.A.M.; Verweij, P.E. Antifungal activity of some Tanzanian plants used traditionally for the treatment of fungal infections. J. Ethnopharmacol. 2006, 108, 124-132.

3. Moshi, M.J.; Kagashe, G.A.B.; Mbwambo, Z.H. Plants used to treat epilepsy by Tanazanian traditional healers. J. Ethnopharmacol. 2005, 97, 327-336.

4. Uwaifo, A.O. The mutagenicities of seven coumarin derivatives and a furan derivative (nimbolide) isolated from three medicinal plants. J. Toxicol. Environ. Health 1984, 13, 521-530.

5. Maneerat, W.; Ritthiwigrom, T.; Cheenpracha, S.; Promgool, T.; Yossathera, K.; Deachathai, S.; Phakhodee, W.; Laphookhieo, S. Bioactive carbazole alkaloids from Clausena wallichii roots. J. Nat. Prod. 2012, 75, 741-746.

6. Songsiang, U.; Thongthoom, T.; Boonyarat, C.; Yenjai, C. Claurailas A-D, cytotoxic carbazole alkaloids from the roots of Clausena harmandiana. J. Nat. Prod. 2011, 74, 208-212.

7. Chakraborty, A.; Chowdhury, B.K.; Bhattacharyya, P. Clausenol and clausenine - two carbazole alkaloids from Clausena anisata. Phytochemistry 1995, 40, 295-298.

8. Ito, C.; Itoigawa, M.; Aizawa, K.; Yoshida, K.; Ruangrungsi, N.; Furukawa, H. $\gamma$-Lactone carbazoles from Clausena anisata. J. Nat. Prod. 2009, 72, 1202-1204.

9. Ito, C.; Katsuno, S.; Itoigawa, M.; Ruangrungsi, N.; Mukainaka, T.; Okuda, M.; Kitagawa, Y.; Tokuda, H.; Nishino, H.; Furukawa, H. New carbazole alkaloids from Clausena anisata with antitumor promoting activity. J. Nat. Prod. 2000, 63, 125-128.

10. Ngadjui, B.T.; Ayafor, J.F.; Sondengam, B.L.; Connolly, J.D. Quinoline and carbazole alkaloids from Clausena anisata. Phytochemistry 1989, 28, 1517-1519.

11. Okorie, D.A. New carbazole alkaloids and coumarins from roots of Clausena anisata. Phytochemistry 1975, 14, 2720-2721.

12. Joshi, B.S.; Kamat, V.N.; Saksena, A.K.; Govindachari, T.R. Structure of heptaphylline, a carbazole alkaloid from Clausena heptaphylla Wt. \& Arn. Tetrahedron Lett. 1967, 8, 4019-4022.

13. Lakshmi, V.; Raj, D.P.K.; Kapil, R.S.; Popli, S.P. Monoterpenoid furanocoumarin lactones from Clausena anisata. Phytochemistry 1984, 23, 2629-2631.

14. Ngadjui, B.T.; Mouncherou, S.M.; Ayafor, J.F.; Sondengam, B.L.; Tillequin, F. Geranyl coumarins from Clausena anisata. Phytochemistry 1991, 30, 2809-2811.

15. Ngadjui, B.T.; Ayafor, J.F.; Sondengam, B.L.; Connolly, J.D. Coumarins from Clausena anisata. Phytochemistry 1989, 28, 585-589.

16. Ngadjui, B.T.; Ayafor, J.F.; Sondengam, B.L.; Connolly, J.D. Prenylated coumarins from the leaves of Clausena anisata. J. Nat. Prod. 1989, 52, 243-247.

17. Ngadjui, B.T.; Ayafor, J.F.; Sondengam, B.L.; Connolly, J.D. Limonoids from Clausena anisata. J. Nat. Prod. 1989, 52, 832-836. 
18. Meva'a, L.M.; Songue, J.L.; Wansi, J.D.; Waffo, A.F.K.; Dongo, E.; Mpondo, T.N.; Sewald, N. Acridone alkaloids and coumarins from the stem bark of Citropsis articulata (Rutaceae). Z. Naturforsch. 2010, 65b, 525-527.

19. Bakar, N.H.A.; Sukari, M.A.; Rahmani, M.; Sharif, A.M.; Khalid, K.; Yusuf, U.K. Chemical constituents from stem bark and roots of Murraya koenigii (Rutaceae). Mal. J. Anal. Sci. 2007, $11,173-176$.

20. Joshi, B.S.; Kamat, V.N.; Gawad, D.H. On structures of girinimbine, mahanimbine, isomahanimbine, koenimbidine and murrayacine. Tetrahedron 1970, 26, 1475-1482.

21. Furukawa, H.; Wu, T.S.; Ohta, T.; Kuoh, C.S. Chemical constituents of Murraya euchrestifolia HAYATA. Structures of novel carbazolequinones and other new carbazole alkaloids. Chem. Pharm. Bull. 1985, 33, 4132-4138.

22. Wu, T.S. Murrayamine-A, murrayamine-B, murrayamine-C and (+)-mahanine, carbazole alkaloids from Murraya euchrestifolia. Phytochemistry 1991, 30, 1048-1051.

23. Begum, R.; Rahman, M.S.; Chowdhury, A.M.S.; Rahman, M.M.; Rashid, M.A. O-methylheptaphylline from Clausena suffruticosa. Nat. Prod. Commun. 2008, 3, 815-818.

24. Lontsi, D.; Ayafor, J.F.; Sondengam, B.L.; Connolly, J.D.; Rycroft, D.S. The use of twodimensional long-range $\delta_{\mathrm{C}} / \delta_{\mathrm{H}}$ correlation in conjunction with the one-dimensional protoncoupled ${ }^{13} \mathrm{C}$ NMR spectrum in the structural elucidation of ekeberginine, a new carbazole alkaloid from Ekebergia senegalensis (Meliaceae). Tetrahedron Lett. 1985, 26, 4249-4252.

25. Ishiguro, K.; Nagata, S.; Fukumoto, H.; Yamaki, M.; Takagi, S.; Isoi, S. A dipeptide derivative from Hypericum japonicum. Phytochemistry 1991, 30, 3639-3641.

26. Isshiki, K.; Asai, Y.; Tanaka, S.; Nishio, M.; Uchida, T.; Okuda, T.; Komatsubara, S.; Sakurai, N. Aurantiamide acetate, a selective cathepsin inhibitor, produced by Aspergillus penicilloides. Biosci. Biotechnol. Biochem. 2001, 65, 1195-1197.

27. Maiti, B.C.; Thomson, R.H. A modified dipeptide from the alga Cystoseira corniculata Hauck. Experientia 1976, 32, 1106-1107.

28. Wahidulla, S.; D'Souza, L.; Kamat, S.Y. Dipeptides from the red alga Acanthospora spicifera. Phytochemistry 1991, 30, 3323-3325.

29. Uemura, D.; Sugiura, K.; Hirata, Y. $O$-Acetyl- $N$-( $N$-benzoyl-L-phenylalanyl)-L-phenylalaninol. Isolation from Euphorbia fischeriana. Chem. Lett. 1975, 537-538.

30. Catalán, C.A.N.; de Heluani, C.S.; Kotowicz, C.; Gedris, T.E.; Herz, W. A linear sesterterpene, two squalene derivatives and two peptide derivatives from Croton hieronymi. Phytochemistry 2003, 64, 625-629.

31. Banerji, A.; Das, R. Aurantiamide and aurantiamide acetate, new amides from Piper aurantiacum Wall. Ind. J. Chem. 1975, 13, 1234-1236.

32. Banerji, A.; Ray, R. Aurantiamides, a new class of modified dipeptides from Piper aurantiacum. Phytochemistry 1981, 20, 2217-2220.

33. Poi, R.; Adityachoudhury, N. Occurrence of two rare amides in Medicago polymorpha. Indian J. Chem. Sect. B 1986, 25, 1245-1246.

34. Talapatra, S.K.; Mallik, A.K.; Talapatra, B. Pongaglabol, a new hydroxyfuranoflavone, and aurantiamide acetate, a dipeptide from the flowers of Pongamia glabra. Phytochemistry 1980, 19, 1199-1202. 
35. Anjaneyulu, A.S.R.; Raju, S.N. Chemical constituents of the bark and leaves of Pterospermum heyneanum Wall. J. Indian Chem. Soc. 1988, 65, 147-148.

36. Sashidhara, K.V.; Rosaiah, J.N.; Tyagi, E.; Shukla, R.; Raghubir, R.; Rajendran, S.M. Rare dipeptide and urea derivatives from roots of Moringa oleifera as potential anti-inflammatory and antinociceptive agents. Eur. J. Med. Chem. 2009, 44, 432-436.

37. Mora, S.; Castro, V.; Povera, L.; Chavarria, M.; Murillo, R. Chemical constituents from Zanthoxylum setulosum (Rutaceae). Boletin Latinoamricano y del Caribe de Plantas Medicinales y Aromaticas 2011, 10, 155-158.

38. Clark, A.M.; Hufford, C.D.; Robertson, L.W. Two metabolites from Aspergillus flavipes. J. Nat. Prod. 1977, 40, 146-151.

39. Talapatra, S.K.; Pal, M.K.; Mallik, A.K.; Talapatra, B. Structure and synthesis of (-)-anabellamide. A new phenylalanine derived ester amide from Anaphalis subumbellata: occurrence of 4'-hydroxydehydrokawain. J. Nat. Prod. 1983, 46, 140-143.

40. McCorkindale, N.J.; Baxter, R.L.; Roy, T.P.; Shields, H.S.; Stewart, R.M.; Hutchinson, S.A. Synthesis and chemistry of $N$-benzoyl- $O$-[ $N^{\prime}$-benzoyl-L-phenylalanyl]-L-phenylalaninol, the major mycelia metabolite of Penicillum canadense. Tetrahedron 1978, 34, 2791-2795.

41. Bird, B.A.; Campbell, I.M. Disposition of mycophenolic acid, brevianamide A, asperphenamate, and ergosterol in solid cultures of Penicillum brevicompactum. Appl. Environ. Microbiol. 1982, 4, 345-348.

42. Nozawa, K.; Udagawad, S.I.; Nakajima, S.; Kawai, K.-I. A dioxopiperazine derivative from Penicillum megasporum. Phytochemistry 1989, 28, 929-931.

43. Ferreira, D.T.; Silva R.B.; Deoliveira, A.B.; Isobe, M.; Braz, R. Dipeptide from the roots of Zeyhera digitalis. J. Brazil. Chem. Soc. 1995, 6, 323-326.

44. de Carvalho, M.G.; Cardozo, M.A.R.; Catunda, F.E.A., Jr.; de Carvalho, A.G. The chemical constituents from Piptadenia gonoacantha (Mart.) J.F. Macbr (pau jacaré). Ann. Brazil. Acad. Sci. 2010, 82, 561-567.

45. Hashim, N.M.; Rahmani, M.; Shamaun, S.S.; Ee, G.C.L.; Sukari, M.A.; Ali, A.M.; Go, R. Dipeptide and xanthones from Artocarpus kemando Miq. J. Med. Plants Res. 2011, 5, 4224-4230.

46. Nielsen, K.F.; Månsson, M.; Rank, C.; Frisvad, J.C.; Larsen, T.O. Dereplication of microbial natural products by LC-DAD-TOFMS. J. Nat. Prod. 2011, 74, 2338-2348.

47. NIST Chemistry WebBook. Available online: http://webbook.nist.gov/chemistry/ (accessed on 15 November 2012).

48. Grossert, J.S.; Cook, M.C.; White, R.L. The influence of structural features on facile McLafferty-type, even-electron rearrangements in tandem mass spectra of carboxylate anions. Rapid Commun. Mass Spectrom. 2006, 20, 1511-1516.

49. Schmidt, A.W.; Reddy, K.R.; Knölker, H.-J. Occurrence, biogenesis, and synthesis of biologically active carbazole alkaloids. Chem. Rev. 2012, 112, 3193-3328.

50. Lin, W.; Wang, Y.; Lin, S.; Li, C.; Zhou, C.; Wang, S.; Huang, H.; Liu, P.; Ye, G.; Shen, X. Induction of cell cycle arrest by the carbazole alkaloid Clauszoline-I from Clausena vestita D. D. Tao via inhibition of the PKC $\delta$ phosphorylation. Eur. J. Med. Chem. 2012, 47, 214-220. 
51. Kok, Y.Y.; Mooi, L.Y.; Ahmad, K.; Sukari, M.A.; Mat, N.; Rahmani, M.; Ali, A.M. Anti-tumour promoting activity and antioxidant properties of girinimbine isolated from the stem bark of Murraya koenigii S. Molecules 2012, 17, 4651-4660.

52. Syam, S.; Abdul, A.B.; Sukari, M.A.; Mohan, S.; Abdelwahab, S.I.; Wah, T.S. The growth suppressing effects of girinimbine on Hepg2 involve induction of apoptosis and cell cycle arrest. Molecules 2011, 16, 7155-7170.

53. Cui, C.-B.; Yan, S.-Y.; Cai, B.; Yao, X.-S. Carbazole alkaloids as new cell cycle inhibitor and apoptosis inducers from Clausena dunniana levl. J. Asian Nat. Prod. Res. 2002, 4, 233-241.

54. Yuan, L.; Li, Y.; Zou, C.; Wang, C.; Gao, J.; Miao, C.; Ma, E.; Sun, T. Synthesis and in vitro antitumor activity of asperphenamate derivatives as autophagy inducer. Bioorg. Med. Chem. Lett. 2012, 22, 2216-2220.

55. Yuan, L.; Wang, J.H.; Sun, T.M. Total synthesis and anticancer activity studies of the stereoisomers of asperphenamate and patriscabratine. Chin. Chem. Lett. 2010, 21, 155-158.

56. Rahman, M.M.; Gray, A.I. A benzoisofuranone derivative and carbazole alkaloids from Murray koenigii and their antimicrobial activity. Phytochemistry 2005, 66, 1601-1606.

57. Adebajo, A.C.; Ayoola, O.F.; Iwalewa, E.O.; Akindahunsi, A.A.; Omisore, N.O.A.; Adewunmi, C.O.; Adenowo, T.K. Anti-trichomonal, biochemical and toxicological activities of methanolic extract and some carbazole alkaloids isolated from the leaves of Murraya koenigii growing in Nigeria. Phytomedicine 2006, 13, 246-254.

58. Ko, F.-N.; Lee, Y.-S.; Wu, T.-S.; Teng, C.-M. Inhibition of cyclooxygenase activity and increase in platelet cyclic-AMP by girinimbine, isolated from Murraya euchrestifolia. Biochem. Pharmacol. 1994, 48, 353-360.

59. Wu, T.-S.; Chan, Y.-Y.; Liou, M.-J.; Lin, F.-W.; Shi, L.-S.; Chen, K.-T. Platelet aggregation inhibitor from Murraya euchrestifolia. Phytother. Res. 1998, 12, S80-S82.

60. Kuo, P.-C.; Hwang, T.-L.; Lin, Y.-T.; Kuo, Y.-C.; Leu, Y.-L. Chemical constituents from Lobelia chinensis and their anti-virus and anti-inflammatory bioactivities. Arch. Pharm. Res. 2011, 34, 715-722.

61. Yang, Z.; Wang, Y.; Wang, Y.; Zhang, Y. Bioassay-guided screening and isolation of $\alpha$-glucosidase and tyrosinase inhibitors from leaves of Morus alba. Food Chem. 2012, 131, 617-625.

62. Balunas, M.J.; Su, B.; Riswan, S.; Fong, H.H.S.; Brueggemeier, R.W.; Pezzuto, J.M.; Kinghorn, A.D. Isolation and characterization of aromatase inhibitors from Brassaiopsis glomerulata (Araliaceae). Phytochem. Lett. 2009, 2, 29-33.

Sample Availability: Samples of the compounds are available from the authors.

(C) 2012 by the authors; licensee MDPI, Basel, Switzerland. This article is an open access article distributed under the terms and conditions of the Creative Commons Attribution license (http://creativecommons.org/licenses/by/3.0/). 